\title{
Small Island, Small Screen: Adapting Black British Fiction
}

\section{Rachel Carroll}

In her 2012 study The Adaptation Industry: The Cultural Economy of Contemporary

Literary Adaptation, Simone Murray suggests that "the processes by which

contemporary literary fiction is created, published, marketed, evaluated for literary prizes and adapted for the screen have lacked sustained academic attention"

(2012:11). Murray is not alone in arguing for the study of contemporary literary culture to be extended beyond the purely textual; James F. English's analysis of the cultural economy of the literary prize (2005), Claire Squires's study of the marketing of contemporary writing (2009) and Jim Collins's examination of shifting categories of literary and popular taste (2010) all provide new frameworks for the analysis of twenty-first century fiction which foreground questions of cultural value extrinsic to the text itself. ${ }^{1}$ In this context, this chapter seeks to combine an appreciation of the significance of extra-textual contexts with close interpretative analysis of a literary adaptation; more specifically, it aims to explore how such contexts can inform the reception of black British fiction through a focus on the $2009 \mathrm{BBC}$ television adaptation of Andrea Levy's 2004 novel Small Island. In 2007 Levy's prize-winning novel was selected for a mass reading event designed to engage the British public in the historical commemoration of the abolition of the slave trade; half a million copies

\footnotetext{
${ }^{1}$ Work within the field of post-colonial literature and theory has played a significant role in the emergence of this new body of knowledge, with the role of the Man Booker Prize in popularising certain modes of post-colonial fiction receiving particular attention; see especially Huggan (2001).
} 
of the novel were distributed to book clubs hosted in major port cities whose histories are widely recognised to be implicated in the Atlantic slave trade (namely Liverpool, Bristol, Glasgow and Hull). In their analysis of the Small Island Read project Danielle Fuller and James Proctor ask "what cultural work ... the novel [was] assumed to perform by the organisers, sponsors, and institutions associated with this event [emphasis added]" (2009: 26); this chapter seeks to extend this question to the BBC television adaptation of Levy's novel, first broadcast on BBC One in 2009.2 The 2009 adaptation is distinctive in bringing the classic adaptation treatment to bear on a contemporary novel focussing on black British history, in foregrounding Black British perspectives and in casting black British actors in leading roles in a period drama. This chapter will begin by situating the 2009 BBC adaptation of Small Island within two critical contexts: the first concerns the production of cultural value within contemporary literary culture and the second concerns the representation of black British identity and history in television drama, including the literary adaptation. It will then go on to examine how the introduction of a contemporary narrative framework to the adaptation of Levy's novel serves to orient this historical fiction towards the future and to construct the birth of a mixed race child as the origin of a multicultural present; in this way the 2009 BBC adaptation can be seen to be extending the "cultural work" (Fuller and Proctor, 2009: 26) of the Small Island Read

\footnotetext{
2 Directed by John Alexander, screenplay Paula Milne and Sarah Williams, and featuring Benedict Cumberbatch (Bernard), Naomie Harris (Hortense), David Oyelowo (Gilbert) and Ruth Wilson (Queenie).
} 
project by providing a dramatic "hinge" (Fuller and Proctor, 2009:30) between past and present.

\section{Constructing Cultural Value: The Small Island Read}

Since its publication in 2004 Andrea Levy's novel has been awarded major literary prizes, adopted by a national mass reading project and adapted for a mainstream, prime-time, television audience. The literary prize, the book club and the adaptation are all distinctive features of contemporary literary culture and, moreover, significant agents in the complex production of cultural value. In Marketing Literature: The Making of Contemporary Writing in Britain, Claire Squires argues that literary prizes "play a crucial role in the interaction between genre and the marketplace, and are one of the forces that come to influence notions of cultural value and literariness" (2009: 97). Indeed, in The Economy of Prestige: Prizes, Awards and the Circulation of Cultural Value, James F. English examines the ways in which the prize serves to authorise "the distribution of esteem and reward on a particular cultural field" (2005: 51). In the context of contemporary British and Commonwealth fiction the Man Booker Prize most exemplifies this function and its success has arguably contributed to the proliferation of literary prizes in recent decades - prizes whose relationship to "genre and the market place" (Squires, 2009: 97) is increasingly nuanced. Where the award of a prestigious literary prize once functioned to strictly demarcate 'literary' fiction from 'mass market' and 'genre' 
fiction, a new generation of awards have arguably contributed to a new genre within the marketplace, one which combines the literary with the popular; in other words, a genre which aims to reconcile the cultural capital more commonly associated with elite taste (and confirmed by the award of the literary prize) with the economic capital ensured by market success (and evidenced by popular sales). ${ }^{3}$ Where the Man Booker prize (launched in 1969) is awarded to the "best, eligible full-length novel in the opinion of the judges," ${ }^{4}$ the Costa Book Award (formerly the Whitbread Book Award, first launched as the Whitbread Literary Award in 1971) recognises "well-written, enjoyable books that [the judges] would strongly recommend anyone to read [emphasis added]"5 and more recently the Orange Prize for fiction (first launched in 1996, and now the Women's Prize for Fiction) celebrates "excellence, originality and accessibility [emphasis added]."6 Levy's Small Island was awarded both the Orange and Whitbread Prizes in the year of its publication and was thus identified as a leading title in the field of what we might call popular literary fiction. The adoption of Levy's novel by an Arts Council funded mass reading project can in part be attributed to this public endorsement not only of its literary merit but also its readability (both "accessible" and "enjoyable"). ${ }^{7}$ Murray has written that "literary

\footnotetext{
${ }^{3}$ As Murray notes, prevailing frameworks for the analysis of constructions of cultural taste (as informed by Pierre Bourdieu) would suggest that "elevation of a cultural property's stock in the economic sphere serves ... to reduce its symbolic capital in inverse proportion" (2012: 117). ${ }^{4}$ Man Booker Prize website, http://www.themanbookerprize.com/entering-the-awards (accessed 31.12.12).

${ }^{5}$ Costa Book Award website, http://www.costabookawards.com/faqs.aspx (accessed 31.12.12)

${ }^{6}$ Orange Prize for Fiction website, http://www.orangeprize.co.uk/ (accessed 31.12.12).

${ }^{7}$ Lang links the "very accessibility of Levy's text" to its "enthusiastic acceptance by a large number of readers in Britain" noting that it is "largely realist ... [and] without much formal inventiveness"
} 
prizes constitute a crucial but commonly overlooked node of the adaptation network" (2012: 104); the sponsored book club, whether publicly funded or commercially endorsed, can be added to this network. ${ }^{8}$ In turn, the increased market visibility and extended readership which follow both literary prize and nationwide book club nominations promise a readymade audience for a prospective screen adaptation, especially one commissioned by a public service broadcaster with a mission to "inform, educate and entertain." ${ }^{9}$ It can be argued that in the years following its publication Small Island became the object of a unique confluence of legitimating forces - the popular literary prize, the book club endorsement and the BBC adaptation - which together served to canonise this novel by a black British writer in specific ways. I would argue that the Small Island Read project is a key reference point when considering the cultural significance of the adaptation with which this chapter is principally concerned.

In her article "Africa in Europe: narrating Black British history in contemporary fiction,"Sofía Muñoz-Valdivieso observes that there have been "two momentous occasions in Britain in the last decade when the presence of the African diaspora in

(2009: 134; 138). Fuller and Proctor suggest that the "centrality of character in Small Island" may be "one reason for the novel's popularity with book groups and other non-academic readers" (2009: 32). ${ }^{8}$ For example, the Richard and Judy Book Club in the UK, televised by Channel 4 from 2004-2009 and now sponsored by retailer WH Smith, and the Oprah Winfrey Book Club, broadcast between 19962011. In May 2010 O, The Oprah Magazine published a Reading Guide to Levy's The Longest Song and in January 2011 the Richard and Judy Book Club listed Levy's Small Island as one of the 100 Books of the Decade. The relationship between the televised book club and hierarchies of literary taste is not without its controversies; see Rooney (2008).

${ }^{9} \mathrm{BBC}$ (British Broadcasting Corporation) website http://www.bbc.co.uk/aboutthebbc/insidethebbc/whoweare/mission and values/ (date accessed 31.12.12) 
the country has come to the fore in media representations and cultural productions" (2010:160): the first being the $50^{\text {th }}$ anniversary of the docking of the SS Empire Windrush at Tilbury in 1948 and the second being the bicentenary of the abolition of the slave trade in the British Empire in 1807. Had its publication not post-dated the 1998 commemorations, Levy's novel might have provided the perfect fictional counterpart to the former. Matthew Mead has argued that "the memorializing of the Windrush moves in contradictory directions, on the one hand ambivalently challenging and on the other unconsciously reaffirming the borders of the nation and the historical conception of Britain as centre of a global empire" (2009:137). In other words, while it serves to mark a significant period in post-war immigration from the British colonies in the Caribbean it may also serve to obscure the presence of black British people in the British Isles prior to 1948. In this context, it is significant that Levy's novel not only reconstructs the experiences of first generation immigrants from the British West Indies, but also contests the myth of the Windrush as a formative first encounter through its focus on the experiences of enlisted Jamaican airman, Gilbert, stationed in North Yorkshire during the war. However, the public reading event for which Levy's novel was selected was not designed to commemorate the landing of the Windrush but rather the abolition of the slave trade. The oddity of this choice is worth some reflection. The experience and legacy of British involvement in the Atlantic slave trade is one which leading Caribbean and British writers had explored in some depth in novels published before 1998, including Kittian-British writer Caryl Phillips's Crossing the River (1993) and 
Cambridge (1991) and British-Guyanese writer Fred D'Aguiar's The Longest Memory (1994) and Feeding the Ghosts (1997). Levy's Small Island can readily be situated within the context of post-colonial literary and studies in its exploration of the historical legacy of the British Empire; however, in terms of popular narrative modes - that is, those on which a mass public reading event is likely to depend-it is not a novel which explicitly requires its readers to confront the realities of slavery. In this context the "cultural work" (2009: 26) to which Fuller and Proctor refer becomes quite complex and extends beyond the immediate narrative concerns of the novel. Fuller and Proctor suggest that the novel is "asked to operate as a hinge between 'the past' (slavery and its abolition; postwar immigration) and the present (contemporary multicultural diversity)" (2009:30). In this act of "state-sanctioned multiculturalism"(Fuller and Proctor, 2009: 31)Small Island is somehow required to stand for slavery and its history without directly addressing it, and to speak for contemporary Britain without explicitly representing it. The black British text is put to work in service to an agenda which seems to obscure its nominal object - the history of slavery - even as it offers to remember it. This paradox is inherent in the anniversary itself, which, in its focus on the abolition rather than the institution of slavery, celebrates the British state as a liberating force even as it acknowledges its role as an agent of oppression. In this context it is not simply the novel's accessibility which it makes it so amenable to the Small Island Read project but also its narrative design; Levy not only creates four distinct characters with compelling storylines but also integrates British and Jamaican perspectives in her narrative 
structure. In doing so the novel gives equal space to white and black perspectives on post-war immigration from the Caribbean. In other words, while its subject matter might seem to have 'minority' appeal in the eyes of the mainstream publishing industry, its narrative approach serves to ensure that white British voices remain central to this black British story. Anouk Lang suggests that:

[The novel's] achievement is that it lays out the complex interrelations of race and class in two locations - the Caribbean and Britain - in such a way as to demonstrate the prejudices and flaws of the black characters while not for a moment exempting its white British and American characters from complicity with wider currents of racism circulating in the 1940s. (2009: 133)

Indeed, the racial prejudices of white British characters are given frank and unapologetic expression in Levy's novel where they are unmediated by the intervention of an omniscient narrator. In this context it is significant that the BBC 2009 adaptation not only omits the narrative perspective of its most explicitly racist white British narrator, Bernard, but also introduces a voiceover which assumes the authority of an omniscient narrator. It could be argued that the former intervention serves to diminish the complicity of its white British narrators in the racism of the period, and as such testifies to the compromises exacted from the black British text in the name of assuring a crossover (that is, white, mainstream) audience. However, the latter intervention arguably serves a more complex populist intent and in some ways ensures that the adaptation fulfils its function as "as a hinge between 'the past' ... and the present" (Fuller and Proctor, 2009: 30) in ways which the source text was 
unable to do. Before turning to a closer comparative analysis of these interventions I wish first to place this literary adaptation within the broader context of representations of black British identity and history on television.

\section{Adapting Black Britain: The Classic Adaptation and Multicultural Television}

In an article published on The Guardian's website in November 2011, British actor Paterson Joseph welcomed the casting of black British actors Solomon Glave and James Howson in the roles of the younger and older Heathcliff in Andrea Arnold's acclaimed film adaptation of Emily Brontë's classic 1847 novel Wuthering Heights: “Black actors belong in British costume drama. After all, we've been around for a lot longer than 1948." The sense that black British actors have been - and continue to be - "locked out of a whole tradition of 'quality', high-budget, often heritage-based drama" (Malik, 2002: 142) is one confirmed in Sarita Malik's Representing Black Britain: Black and Asian Images on Television. In this historical study of British television, Malik suggests that "The lengthy and pre-meditative process involved in drama production (deliberate decisions about scripting, casting, directing and scheduling), has positioned it at the heart of talks around multicultural content, integrated casting, narrative diversity and minority access"'(2002: 135). Malik argues that the situation comedy was the key vehicle through which British multiculturalism became visible in the 1970s, through popular series such as Till Death Us Do Part (BBC1, 1966-8, 1972, 1974-5), Curry and Chips (LWT, 1969), It Ain't 
Half Hot Mum (BBC, 1974-81), Rising Damp (Yorkshire TV / ITV, 1974-8) and Mind Your Language (LWT / ITV, 1977-79). While some of these comedies provided opportunities for black British actors to pursue an acting career in television, others perpetuated the theatrical tradition of 'blackface' performance, with white British actors 'blacking up' for comic effect. Moreover, Malik observes that "many of the comedies 'about race', were actually comedies about Blacks signifying trouble; trouble with the neighbours, trouble with language, trouble with fitting in. . . [emphasis in original]" (2002:97)." Malik notes that from the early 1980s, the increasing popularity of long-running drama series / serials set in contemporary Britain established a new small screen stage for black British actors; however, by deploying black British actors to denote the modernity of contemporary urban contexts, these dramas did nothing to remedy their exclusion from the more prestigious genres of period drama, of which the classic adaptation is a prominent example.

Literary adaptation continues to be a central feature of the "'quality', high-budget, often heritage-based drama"(Malik, 2002: 142), with adaptations of 'classic' novels by nineteenth century authors such as Jane Austen and Charles Dickens proving a recurring staple in broadcast schedules, occupying sought after prime time slots and taking pride of place in Sunday evening and public holiday programming. Such adaptations can be relied upon to attract significant viewing audiences and to feature prominently both in the quality press review pages and in the shortlists for national and international television awards; granted economic value by the market 
and cultural value by institutionalised arbiters of mainstream taste, the genre's capacity to combine both critical and commercial success goes some way to explain the repeated commission of new adaptations of the same set of source texts. Moreover, the extension of the aesthetic idiom of the historical period drama - with its privileging of notions of 'authenticity', especially in relation to the material cultures of costume, artefacts and interiors - to the classic adaptation arguably serves to gloss over the extent to which the historical period in question is itself mediated by the prevailing narrative conventions and dominant ideologies of the time. The prominence of adaptations of a very historically and culturally specific set of source texts within the version of national cultural heritage propagated by the mass medium of television both at home and abroad (the classic adaptation being a prime cultural export) has ideological implications which have proved the focus of key interventions in adaptations studies. Sarah Cardwell cites Paul Kerr as playing a key role in bringing critical attention to the "institutional, social and ideological" (2002: 78) contexts within which the classic adaptation on television is produced and consumed. In this way, "classic-novel adaptations" have been seen as "operat[ing] as part of an ideological project to elevate and perpetuate an elite literary culture ... and to build reactionary nostalgia for a mythologised 'ideal' era in Britain's colonial past" (2002: 78). ${ }^{10}$ Indeed, these adaptations tend to focus on an era when the power and wealth of the British Empire was at its height but on texts which give little

\footnotetext{
${ }^{10}$ For an analysis of how the heritage film engages in "the artful and spectacular projection of an elite, conservative vision of the national past" see Higson (1996).
} 
representation to the inequities of colonial rule; they offer contemporary audiences a vision of national identity as rooted in an imperial past and of a Britishness implicitly equated with whiteness. In terms of cultural representation, the experience of non-white colonial subjects beyond the British Isles and the historical presence of black British people within them are rendered invisible; in terms of cultural industry, black British actors are largely precluded from the creative and professional opportunities which such productions present. Classic adaptations have often played a formative role in establishing actors within the national consciousness and can offer a prestigious platform for the launch or revival of careers in television drama. However, the striking absence of integrated casting strategies in classic adaptations has meant that talented black British actors are denied the opportunities extended to their white peers. ${ }^{11}$ Indeed, in recent years leading black British actors have turned to the US for opportunities which the British television industry seems unable to match, including Marianne Jean-Baptiste (Without a Trace, 2002-9), Idris Elba (The Wire, 2002-4) and David Harewood (Homeland 2011-12). ${ }^{12}$

\footnotetext{
${ }^{11}$ Ayanna Thompson describes the ethos of 'integrated', or 'colorblind,' casting as follows: "neither the race nor the ethnicity of an actor should prevent her or him from playing a role as long as she pr he was the best actor available" (2006: 6).

${ }^{12}$ Marianne Jean-Baptiste was the first Black British actor to be nominated for an Academy Award for her performance in Mike Leigh's Secrets $\mathcal{E}$ Lies in 1996; the following year she was omitted from a showcase of (exclusively white) young British acting talent hosted by British Screen for the $50^{\text {th }}$ Anniversary of the Cannes Film Festival. Jean-Baptiste was reported as commenting "What more do they want? Maybe I should have done a soap. It is a shame on Britain. I see myself as British and I want to be celebrated by Britain." The Guardian, 15 ${ }^{\text {th }}$ May, 1997, http://www.guardian.co.uk/film/1997/may/15/news.danglaister (accessed 1.1.13).
} 
The extension of the 'classic adaptation' treatment - defined by an aesthetics of fidelity to the source text, an attitude of deference to its author, and narrative strategies of historical realism - to a contemporary novel can become instrumental in the popular 'canonisation' of that text as a contemporary classic. Tracey L. Walters has written that:

black writers in Britain have been rendered invisible mainly because most of the literature they produce is ushered into a separate white canon distinct from the larger body of work produced by white writers. . Every few years, though, the literary establishment recognises a Black writer as British. (2005: 314)

In this context, the commission of an adaptation of Small Island by a national broadcasting organisation with a public service mandate, and the production of this adaptation within the conventions of a genre associated with high cultural value and prestige, might seem to mark a gesture of 'recognition' on the part of the cultural establishment. While the 2009 BBC adaptation of Levy's novel is a largely faithful in tone and content, two significant changes are made to its narrative structure: the first concerns the omission of one of the four narrative voices which make up the multiple narrative structure of the novel and the second concerns the introduction of a prominent voiceover whose function is equivalent to that of an omniscient narrator. I will argue that these interventions have important implications for the representation of the history and future of British multiculturalism in this adaptation of Levy's source text. 
Framing the Black British Family: Narrative Voices in the 2009 BBC Small Island

Andrea Levy's novel opens with an arresting and provocative account of a white child's encounter with an adult man during a family visit to the 1924 British Empire Exhibition at Wembley:

But then suddenly there was a man. An African man. A black man who looked like he had been carved from melting chocolate... A monkey man sweating a smell of mothballs. Blacker than when you smudge your face with a sooty cork. The droplets of sweat on his forehead glistened and shone like jewels. His lips were brown, not pink like they should be, and they bulged with air like bicycle tyres. His hair was woolly as a black shorn sheep. His nose, squashed flat, had two nostrils big as train tunnels. And he was looking at me. (2004: 6)

In the context of the novel the offensive nature of this language is mitigated by its attribution to the perspective of a child and by the parodic subtext which underlines this litany of racial stereotypes. The adaptation of this particular first person narrative perspective represents specific challenges if the audience is not to be alienated; the way in which this scene is adapted in the 2009 BBC television adaptation tells us much about its dramatic priorities. 
In the adaptation this scene is not directly depicted but retrospectively recalled by the adult Queenie (Ruth Wilson); moreover, the memory is triggered during a moment of domestic intimacy with her Jamaican lover, Michael (Ashley Walters). As they talk by the kitchen range, Queenie lapses into a kind of reverie; the camera lingers on her entranced expression and the viewer's identification with her rapture is uninterrupted by reaction shots which might otherwise prompt us to consider Michael's perspective on this objectifying episode. In the novel Queenie's first encounter with a man of African origin is slyly sexualised when one of her father's farmhands presses her to kiss him; however, her confusion and embarrassment is defused when the "big nigger man" (Levy: 2004, 6) civilly offers her his hand to shake instead. The possibility that this memory might be the source of a racialised sexual desire is evidently not precluded in the television adaptation, but it is dignified by being incorporated into a heterosexual romance narrative. Moreover, Michael is enlisted to play a willing role in the white woman's fantasy; in a gesture that echoes that of the African man in the novel, he takes her hand but this time kisses it. I would suggest that the translation of this scene in the 2009 adaptation is significant in two ways: it is indicative of the ways in which white British racism is contained and defused in the adaptation and of the way in which the conception, birth and adoption of a mixed race child is foregrounded.

The use of multiple narrative perspectives is a common device within literary fiction and this novel assists the reader in navigating between linguistically marked voices 
by indicating the identity of the speaker in each chapter heading. The narration of Andrea Levy's novel alternates between four first person narrators, two male and two female, two white British and two Jamaican: Queenie, Hortense, Gilbert and Bernard. The narrative point of view of three of these narrators - Queenie, Hortense and Gilbert - is retained in the television adaptation which depicts unfolding events from their respective perspectives. However, while Bernard (Benedict Cumberbatch) remains a key character within Queenie's story and a passing character in Hortense and Gilbert's his own narrative, and crucially his experiences as a British soldier in colonial India, is omitted. Of the four narrators in Levy's novel, three give voice to opinions or perspectives informed by colonial discourses of race (Gilbert perhaps the only exception), but it is Bernard who gives voice to the most unmitigated racial prejudice with his repeated and contemptuous references to “chocolate-drop troops from West Africa (Levy, 2004: 366), “"bloody coolies” (Levy, 2004:369) and "wretched, simpering little wog[s] (Levy, 2004: 393)." His language is depicted as motivated rather than casual and is directly allied to his conviction both in the legitimacy of the British Empire and the illegitimacy of its subjects' right to live and work in the Mother Country. Moreover, his encounters with non-white British subjects serve not to broaden but to narrow his understanding of Britishness; he returns from a war fought against fascism convinced of the necessity for racial segregation:

The war was fought so people might live amongst their own kind. Quite simple. Everyone had a place. England for the English and the West Indies 
for these coloured people. ... I've nothing against them in their place. But their place isn't here. . . These brown gadabouts were nothing but trouble. (Levy, 2004: 469)

The omission of Bernard's narrative perspective from the 2009 BBC adaptation has the effect not only of removing a wider colonial context but also of diminishing the extent to which racist attitudes are given expression by its white British protagonists.

A further effect of the exclusion of Bernard's narrative point of view from the television adaptation is to upset the gendered symmetry of the novel's narrative structure and to emphasise a triangular heterosexual romance plot whose object is not the remaining male narrator, Gilbert (David Oyelowo), but Michael, whose function in the narrative is characterised by his absence (leaving his family home to enlist, returning to war, being assumed lost in combat, emigrating to Canada). In the 2009 adaptation Michael's absence is figured by his photograph, an object cherished both by Hortense (Naomie Harris), who harbours a lifelong unrequited love for her adoptive brother, and Queenie, his war-time lover and future mother of his son; tucked into Queenie's mirror and Hortense's wallet, the private longing and wistful gazes which this photograph attracts is a recurring motif in the adaptation. Chance intervenes on more than one occasion to ensure that the two women remain in ignorance of their shared passion for Michael; indeed, their dual ownership of Michael's image serves less to construct Hortense and Queenie as romantic and 
sexual rivals than to underline the shared nature of their experience. Both women are depicted as alienated from their family home, undertaking marriages for pragmatic rather than romantic ends and motivated by a desire for social mobility. Indeed, property plays a key role in their pursuit of the latter; Queenie rents out rooms in the house she has inherited from her husband (who is missing, presumed dead) and Hortense's skills in domestic management, depicted as comically wanting in the cramped space of the rented room she and Gilbert first share, come into their ascendancy when Gilbert enters the property market by purchasing a dilapidated property for renovation. These parallels prepare the way for the maternal substitution with which the novel concludes and which prefaces the 2009 adaptation's most innovative departure from Levy's narrative structure.

The adaptation closes with Gilbert and Hortense moving into their own home with their newly acquired adopted baby; as she gently loosens his swaddling blankets, Hortense discovers an envelope containing a photograph of his birth mother. An unexpected flash forward - the first employed in a drama which has otherwise been firmly located in the past - follows a black woman as she enters the same property, but now in the present day, where her two children are discovered poring over a family album with their grandfather, an activity evidently instigated by the older man who admits to doing "the genealogy thing." It is only in these closing scenes of the second and final feature film length episode of the adaptation that the voice of the narrator is revealed as belonging to a character in the drama, rather than as a 
disembodied narrative device. Moreover, it belongs to a character who does not feature in Levy's source text: namely, Queenie and Michael's unnamed adult son, now a grandfather and our contemporary. The viewer's ability to identify the voiceover with the actor playing this new character is significantly assisted by the casting of one of the most widely recognised and distinguished black British actors of his generation: Hugh Quarshie. The casting of the classically trained Quarshie brings with it a set of extra-textual meanings which place the adaptation within the broader context of the history of black British actors, given that Quarshie became a figurehead for the Royal Shakespeare Company's adoption of the practice of integrated casting in the 1980s. ${ }^{13}$

A close-up of the photograph album identifies "great grandma" as Hortense pictured in a graduation gown, an image which anticipates an event beyond the action of the main drama and which assures the reader that her professional ambitions where not thwarted by British colonial double standards. However, it also reveals an image with which the viewer is familiar but which evokes the grandchildren to exchange glances of consternation - that is, an image of Queenie, immediately recognisable from the preceding action and now identified as the white

\footnotetext{
${ }^{13}$ Quarshie made RSC history when he was cast as Hotspur in Henry IV (1982) and as Tybalt in Romeo and Juliet and Banquo in Macbeth (1986); see Daileader (2000). It was not until 2000 that the RSC cast a Black British actor in the role of an English king; the actor was David Oyelowo, who plays Gilbert in Small Island. Integrated, or 'colorblind,' casting, first pioneered by Joseph Papp's New York Shakespeare Festival in the 1950s, is a practice which has been extended to film and television adaptations of Shakespeare's plays but not to adaptations of classic novels; it is the absence of integrated casting in UK television drama productions which makes the prominence of period drama so problematic for Black British actors.
} 
paternal grandmother of the children. The birth of a child, as represented in fiction, is routinely figured a signifying an alternative futurity; in the context of post-colonial fiction, the mixed race child is burdened with a particular kind of generational legacy ${ }^{14}$ However, Queenie's decision to give up her child in some way contradicts the reading of his birth as a symbol the "birth of multicultural Britain" (Grmelová, 2010: 83); her conviction in the impossibility of being a white mother to a mixed raced child, actually confirms the racial segregation which Bernard and his neighbours advocate and which Queenie has previously seemed to challenge. Moreover, the novel's depiction of Hortense and Gilbert's willingness to assume the parenting of their landlady's child evokes a racial politics of reproduction which is troubling. While the BBC adaptation infers a thwarted desire for motherhood on the part of Queenie prior to her pregnancy, Hortense does not exhibit or express any maternal ambitions; when she is commandeered to assist Queenie in her delivery her reaction is one of distaste. In this scene her failure to demonstrate an innate capacity for midwifery cannot help but echo the famous scene in David O. Selznick's 1939 film Gone With the Wind where the inadequacy of Scarlett O'Hara's young maid (played by Butterfly McQueen) is the object of racialised comedy. In this context Hortense's willingness to adopt Queenie's child, and to implicitly postpone her professional ambitions and forego her own experience of maternity, seems hard to

\footnotetext{
${ }^{14}$ Levy is not alone in deploying this motif and, in her analysis of Zadie Smith's 2000 novel White Teeth, Fowler argues that "The child she [Irie] conceives near the end of the novel, with Magid or Millat, acts further to disrupt notions of binaries and point to the prevalence of racial and cultural multiplicity in the future in Britain" (2008: 13).
} 
explain; in ways which are historically familiar a black woman is placed in service to white women's reproductive sexuality, and her willingness to nurse and rear another woman's child attributed to altruism rather than to economic or political hierarchy.

However, the introduction of the adult version of this infant serves in some way to recuperate this problematic narrative climax; his status as a respected, trusted and present father to his own children and their children retrospectively affirms his own family roots. The image of the doting domesticated grandfather, baby-sitting his daughter's children and gently instructing them in their maternal legacy in some ways restores the image of black paternity, which has otherwise been depicted as punishing or absent. The family home is a key location for British television drama; the location of this scene within a property purchased by first generation Caribbean immigrants confirms their place within the British property owning tradition, situates their present within a historical continuity with the past and presents a scene in which British and black identity are identical. ${ }^{15}$ Most significantly, in dramatic terms, it identifies the voice of the narrator as Queenie and Michael's son; his interventions in the storytelling process now take on a political dimension as they can be seen retrospectively to serve as the "hinge" between past and present to which Fuller and Proctor refer (2009: 30). I would argue that this orientation

\footnotetext{
15James Proctor has argued that the "dwelling place was ... the site at which the regulation, policing and deferral of black settlement were most effectively played out" (2003: 22).
} 
towards the future has important effects in terms of the 'cultural work' of the 2009 BBC adaptation; it perhaps confirms that it is less concerned with confronting historic white British racism than with legitimising contemporary black British identity through the mobilisation of heritage motifs.

To conclude, the 2009 BBC television adaptation of Small Island deploys traditional narrative and dramatic techniques in its efforts to engage a mass audience in identification with its key characters, both black and white. In doing so it arguably underplays the representation of racist sentiment by ordinary British subjects which is given such frank and provocative expression in Levy's novel. However, the deployment of a contemporary narrative framework serves to suggest the continuity and integration of mixed race British heritage through a focus on the family as a key holding frame for national identity. While the adaptation does not situate itself within a tradition of critical anti-racist social realist drama, it employs the conventions of populist period drama to subtly reconfigure assumptions about what constitutes a British family history. 


\section{Bibliography}

Cardwell, Sarah. (2002), Adaptation Revisited: Television and the Classic Novel.

Manchester and New York: Manchester University Press.

Collins, Jim. (2010), Bring on the Books for Everybody: How Literary Culture Became Popular Culture. Durham and London: Duke University Press.

Daileader, Celia R. (2000), "Casting black actors: beyond Othellophilia." Shakespeare and Race. Ed. Catherine M.S Alexander and Stanley Wells. Cambridge: Cambridge University Press.

English, James F. (2005), The Economy of Prestige: Prizes, Awards and the Circulation of Cultural Value. Cambridge, Massachusetts; London, England: Harvard University Press.

Fowler, Corinne. (2008), “A Tale of Two Novels: Developing a Devolved Approach to Black British Writing." The Journal of Commonwealth Writing 43 (2008).

Fuller, Danielle and James Proctor. (2009), “Reading as ‘social glue’? Book Groups, Multiculture, and the Small Island Read 2007." Moving Worlds 9:2, 26-40.

Gone With the Wind. USA, 1939. Dir. David O. Selznick.

Grmelová, Anna. (2010), “From Loneliness to Encounter: London in the Windrush generation novels of Sam Selvon and Andrea Levy." Litteraria Pragensia: Studies in Literature and Culture 20:40, 70-84.

Higson, Andrew. (1996), “The Heritage Film and British Cinema.” Dissolving Views: Key Writings on British Cinema. London: Continuum. 
Huggan, Graham. (2001), "Prizing Otherness: A short history of the Booker.” The Postcolonial Exotic: Marketing the Margins. London: Routledge, pp105-123. Joseph, Paterson. (2011), “Why Wuthering Heights Gives Me Hope.” The Guardian. $11^{\text {th }}$ November.

http://www.guardian.co.uk/commentisfree/2011/nov/11/wuthering-heightsblack-actors (Accessed 2.1.13).

Lang, Anouk. (2009), "'Enthralling but at the same time disturbing': Challenging the readers of Small Island." The Journal of Commonwealth Studies 44:2, 123-140.

Levy, Andrea. (2004), Small Island. London: Headline.

Malik, Sarita. (2002), Representing Black Britain: Black and Asian Images on Television. London: Sage.

Mead, Matthew. (2009), “Empire Windrush: The cultural memory of an imaginary arrival." Journal of Postcolonial Writing 45:2, 137-149.

Muñoz-Valdivieso, Sofía. (2010), “Africa in Europe: narrating Black British history in contemporary fiction." Journal of European Studies 40:2, 159-174.

Murray, Simone. (2012), The Adaptation Industry: The Cultural Economy of Contemporary Literary Adaptation. New York and London: Routledge.

Procter, James. (2003), Dwelling Places: Postwar Black British Writing. Manchester and New York: Manchester University Press.

Rooney, Kathleen. (2008), “Jonathan Frantzen Versus Oprah Winfrey: Disses, Disinvitation, and Disingenuousness." Reading with Oprah: The Book Club That Changed the America. University of Arkansas Press, pp. 33-66. 
Small Island. UK, BBC, 2009. Dir. John Alexander.

Squires, Claire. (2009), Marketing Literature: The Making of Contemporary Writing in Britain. London: Palgrave Macmillan.

Thompson, Ayanna. (2006), "Practicing a Theory / Theorizing a Practice: An Introduction to Shakespearean Colorblind Casting." Colorblind Shakespeare: New Perspectives on Race and Performance. Ed. Ayanna Thompson. New York; London: Routledge.

Walters, Tracey L. (2005), “’We're All English Now Mate, Like It Or Lump It”: The Black / Britishness of Zadie Smith's White Teeth." Write Black, Write British: From Post Colonial to Black British Literature. Ed. Kadija Sesay. London: Hansib. 